\title{
ANAPHYLAXIS AFTER IMMUNIZATION
}

${ }^{1}$ Belarusian Medical Academy of Post-Graduate Education, Department of ambulatory pediatrics, Minsk, Belarus.

\section{INTRODUCTION}

Control, record and analysis of side effects following immunization play a vital role in ensuring the safety of vaccination

Adverse Events Following Immunization (AEFI) - unforeseen adverse body reactions to immunobiological drugs administration at the dose specified in the instructions for use Anaphylaxis - is a potentially fatal generalized hypersensitivity reaction Anaphylaxis clinical presentation - is a symptom complex, including cardiovascular cutaneous, respiratory, gastrointestinal and other symptoms to a variable degree of its combination

Reducing the number of such serious vaccine-associated reactions is high-priority problem facing allergologists-immunologists and pediatricians

The actual prevalence of anaphylaxis during immunization is unknown

Under-Diagnosis of anaphylaxis - numerous variations in the clinical presentation of the disease (e.g., in terms of severity - from minor to fatal, a combination of symptoms the presence or absence of urticaria symptoms from various systems, etc., the age of the patient)

\section{CONTACT}

\section{Anna Ruban}

Associate Professor, MD, Ph.D.

annaruban7@.yandex.ru

\section{CASE PRESENTATION SUMMARY}

According to official data, for the period 2012-2017 in the Republic of Belarus 22 serious AEFI (except abscesses) were recorded

5 cases of anaphylaxis were among them The structure of the AEFI is shown in the diagram

The age of the patients ranged from 7 to 58 years. 2 cases of anaphylaxis were recorded in children at the age of 7 and 17 years

Characteristics of the cases of

postvaccination anaphylaxis are summarized in Table

Emergency care for patients was provided in accordance with the national protocols for managing patients with anaphylaxis

THE STRUCTURE OF SEVERE AEF FOR THE PERIOD 2012-2017 IN THE REPUBLIC OF BELARUS

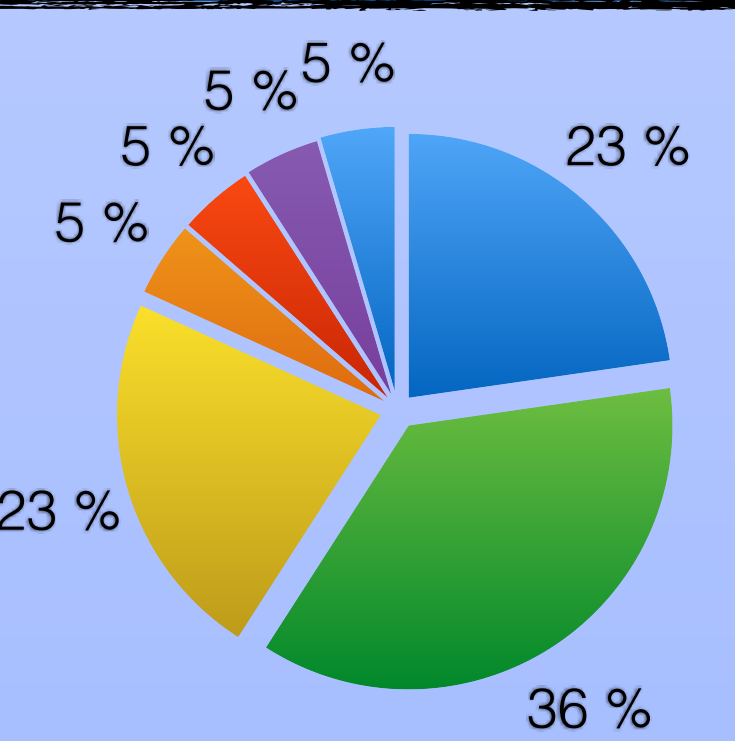

- Anaphylaxis

Convulsive syndrome

Angioedema+urticaria

Hyperthermal syndrome

- Serum sickness

- Thrombocytopenic purpura

- Severe local reaction expected number anaphylaxis?
In a year - in the Republic of Belarus - about 10000000 vaccine doses are introduced Average frequency $-1.31 / 1000000$ doses $^{*}$

Theoretically - we expect 13 cases of anaphylaxis in the Republic of Belarus

In fact, we have 5 cases of anaphylaxis for 6 years $(0.83 / \mathrm{y})$ or 15.6 times less than the

Where are the remaining cases of

\section{ANAPHYLAXIS CASES CHARACTERISTICS}

\begin{tabular}{|c|c|c|c|c|c|c|}
\hline $\begin{array}{l}\text { Patient } \\
\text { age, } \\
\text { y/sex }\end{array}$ & $\begin{array}{l}\text { Vaccine/ } \\
\text { serum }\end{array}$ & $\begin{array}{l}\text { Onset after } \\
\text { vaccination }\end{array}$ & Symptoms & Outcome & $\begin{array}{l}\text { Prevalence in year } \\
\text { of detection }\end{array}$ & $\begin{array}{l}\text { Prevalence for } \\
\text { the entire period } \\
\text { of observation }\end{array}$ \\
\hline $31 / \mathrm{M}$ & dT & $\begin{array}{l}\text { onset } \\
\text { immediate }\end{array}$ & $\begin{array}{l}\text { isolated critical blood } \\
\text { pressure }\end{array}$ & $\begin{array}{l}\text { patient } \\
\text { recovered }\end{array}$ & $\begin{array}{l}3.23 \text { cases per } \\
1,000,000 \text { doses }\end{array}$ & \multirow{2}{*}{$\begin{array}{l}0.52 \text { cases per } \\
1,000,000 \text { doses }\end{array}$} \\
\hline $17 / \mathrm{F}$ & $d T$ & onset $<15 \mathrm{~min}$ & $\begin{array}{l}\text { gastrointestinal and } \\
\text { cardiovascular }\end{array}$ & $\begin{array}{l}\text { patient } \\
\text { recovered }\end{array}$ & $\begin{array}{l}0.67 \text { cases per } \\
1,000,000 \text { doses }\end{array}$ & \\
\hline \multirow[t]{2}{*}{$42 / \mathrm{M}$} & $\begin{array}{l}\text { anti-tetanus } \\
\text { anatoxin }\end{array}$ & \multirow{2}{*}{ onset $<60 \mathrm{~min}$} & \multirow{2}{*}{$\begin{array}{l}\text { cutaneous and } \\
\text { cardiovascular }\end{array}$} & \multirow{2}{*}{$\begin{array}{l}\text { patient } \\
\text { recovered }\end{array}$} & $\begin{array}{l}11.9 \text { cases per } \\
1,000,000 \text { doses } \\
\text { anti-tetanus } \\
\text { anatoxin }\end{array}$ & $\begin{array}{l}2,73 \text { cases per } \\
1,000,000 \text { doses } \\
\text { anti-tetanus } \\
\text { anatoxin }\end{array}$ \\
\hline & $\begin{array}{l}\text { antitetanic } \\
\text { serum }\end{array}$ & & & & $\begin{array}{l}61.6 \text { cases per } \\
1,000,000 \text { doses } \\
\text { antitetanic serum }\end{array}$ & $\begin{array}{l}1.8 \text { cases per } \\
1,000,000 \text { doses } \\
\text { antitetanic serum }\end{array}$ \\
\hline $58 / \mathrm{M}$ & $\begin{array}{l}\text { anti-botulinic } \\
\text { serum type A }\end{array}$ & onset $<10 \mathrm{~min}$ & $\begin{array}{l}\text { cardiovascular and } \\
\text { respiratory }\end{array}$ & $\begin{array}{l}\text { patient } \\
\text { recovered }\end{array}$ & 1 to 28 doses & 1 to 279 doses \\
\hline 7/F & RV MMR & $\begin{array}{l}\text { onset } \\
\text { immediate }\end{array}$ & $\begin{array}{l}\text { weakness, pallor, a } \\
\text { single vomiting, rapid } \\
\text { loss of consciousness } \\
\text { with a lack of pulse } \\
\text { and respiration }\end{array}$ & fatal & $\begin{array}{l}4.7 \text { cases per } \\
1,000,000 \text { doses }\end{array}$ & $\begin{array}{l}0.77 \text { cases per } \\
1,000,000 \text { doses }\end{array}$ \\
\hline
\end{tabular}

\section{REFERENCES}

${ }^{*}$ Michael M. McNeil, Eric S. Weintraub et al. Risk of anaphylaxis after vaccination in children and adults. J Allergy Clin Immunol. 2016 Mar; 137(3): 868-878. doi: 10.1016/j.jaci.2015.07.048 